\title{
On Symbolic Depiction of the Background in Robert Stevenson's Short Story
}

\author{
Lai Peng \\ School of Foreign Languages, Sun Yat-sen University, China
}

Copyright $(2016$ by authors, all rights reserved. Authors agree that this article remains permanently open access under the terms of the Creative Commons Attribution License 4.0 International License

\begin{abstract}
This paper analyzes Robert Stevenson's short story (Markheim) by probing into the symbolic meaning of objects and sounds in the background of a murder scene. Different from most short stories by other writers, who tend to express the theme by creating sophisticated characters and constructing complicated plot, this story lays unusual stress on the background and endows it with symbolic significance and textual prominence. The symbolic contrast between brightness and darkness at the place of the murder and the symbolic contrast between silence and sounds in the surroundings of the scene can be interpreted as the conflict between good and evil in Markheim's mind after he murdered the shop keeper and thus committed a sin. The symbolic depiction of the background helps to build up the psychological tension within the murderer and contributes to the manifestation of the theme: the struggle between good and evil and the conquest of good over evil. Symbolism in background depiction is shown by this paper to be an effective literary technique for revealing the theme and is thus worth drawing on even by contemporary writers.
\end{abstract}

Keywords Symbolism, Background, Theme, Short Story, Markheim

\section{Introduction}

Robert Louis Stevenson, famous for his novel "Treasure Island", is known as a master of suspense, adept at creating an atmosphere of horror and mystery. In addition to his well-known novels, Robert Stevenson has also written a number of impressive short stories. Markheim is an excellent piece among them, a murder story in an atmosphere of horror, which is characteristic of most of Stevenson's works. Different from most short stories by other writers, who usually express the theme of the story by creating sophisticated characters or inventing intricate plot, this story by Robert Stevenson has only one main character and very simple plot: Markheim, who murdered a shop keeper (the curios dealer) on a Christmas Day in order to rob the treasure in the antique shop, found himself in an atmosphere of terror on account of his guilty conscience, then there suddenly appeared in front of him a mysterious visitor, who had superior knowledge of Markheim's situation and offered him advice to complete the robbery and get away unnoticed. "Evil and good run strong in me, hailing me both ways" [1], Markheim said to him, refusing his advice and help and deciding to cease from evil action and turn to the good forces. The words he said express a theme that's central to much of Stevenson's best works: love of good and hatred of evil. In this story, the conflict between the forces of good and evil is starkly presented, not through its plot, as the plot is utterly simple, nor through its characters, as the main character is only Markheim, but through enhancing the background that the character is in and endowing things in the surroundings with symbolic meaning. Although this is a story written in the 19th century, the symbolic writing technique which creates contrast and conflict between two opposing forces is still worth drawing on even by contemporary writers. Besides, the story setting involves Stock Exchange (which symbolizes the force that drags people down) and Christmas Day (which symbolizes the force that raises people up), both of which still exist in the contemporary world, so this seemingly old story can enlighten even people today by its symbolic implication.

\section{Symbolic Depiction of Objects in the Background}

Background depiction in a short story is usually treated as an auxiliary means, for most story writers tend to lay more stress on plot and characters. However, Robert Stevenson's short story Markheim is an excellent example to show how background depiction can be made the main means to stress the theme. In this story, the writer resorts to meticulous description of objects and sounds in the background to create a kind of special atmosphere for the story and to reveal the psychological tension in the murderer. What's more, objects and sounds in the surroundings are made symbolic. As what will be shown below, Stevenson's particular technique in 
emphasizing the background and using symbolism in background depiction has enabled the horror scene to achieve artistic effect and symbolic significance, and has successfully strengthened the theme - the conflict of good and evil in the murderer's mind.

The murder took place in an antique shop. Most objects in this background are endowed with symbolic meaning. Most objects in this background thus contribute to the development and manifestation of the theme, for they all have a considerable impact on the murderer's psychological state - the conflict between the forces of good and evil in his mind. When reading this story, readers can not help feeling a certain peculiar atmosphere: horrible, mysterious and supernatural. After the killing, Markheim, the murderer, walked in the empty shop, searching for money, while candles, shadows, mirrors and clocks etc. all around seemed to startle him. They create not only psychological tension in the murderer's mind but also psychological suspense in the readers' heart. The symbolic implications of the light, the shadow and the front door of the shop are analyzed below.

The light (e.g. candlelight, daylight and skylight) in this story symbolizes the force of good and the call of brightness, as opposed to the evil force and darkness. As the shop was dark, when Markheim entered it, the candlelight that fell on him made him feel uneasy, and he looked aside, unable to look at the shop keeper in the eye. This reveals the conflict between good and evil in his mind before he conducted the killing. The wavering candlelight in the shop reflects "mingled shine and darkness" [1], just like the fighting of the two forces in his heart. The candle and its flame appeared quite a few times throughout the story, creating an atmosphere of horror to the murderer and carrying a symbolic meaning to the theme. After killing the shop keeper, Markheim glanced at the front door of the shop, seeing skylight filter down on the threshold, a kind of light that was exceedingly faint, as if "in a strip of doubtful brightness" [1]. This kind of "faint, foggy daylight"[1] shows that at the time the force of good was weak. But "a long slit of daylight like a pointing finger" [1] implies that Markheim felt guilty at conscience for the murder and was afraid of being found out, so the daylight is like the good force, pointing at him, accusing him.

Shadows appeared from time to time throughout the story, moving, following Markheim wherever he went in the shop, not only enhancing the atmosphere of horror, but also emphasizing the symbolic significance of the story. In the end the shadow ("a faceless thing", "something nameless"[1]) turned out to be that of the supernatural visitor. The sudden appearance of this omnipotent visitor who knew the complete situation seemed to be quite illogical. He must be a symbolic image. At first he appeared to be the devil, who offered to help Markheim with his evil deeds, but at the end of the story readers may understand him to be the Christ, tactfully saving Markheim from the evil force and reviving the good side of him. This stands to reason, as the story took place on a Christmas Day when the Savior was born. But most probably, the shadow of this mysterious visitor is simply another Markheim. It seems absurd to make such an assumption, but from the perspective of psychology, it is possible that due to the psychological tension in Markheim, his soul is mysteriously split into two - the good side of Markheim and the evil side of Markheim. The depiction of the dual nature of man and the alternative transformation between the two sides of a man is also found in Robert Stevenson's other works like Dr Jekyll and Mr. Hyde.[2] So the mysterious visitor probably represents one side of Markheim. He is actually a shadow of Markheim himself: his alter ego. This can be proved from the story itself: when Markheim heard the "delicate footing"[1], he felt the presence of "a faceless thing, and yet has eyes to see with, and again it was a shadow of himself." [1] When the mysterious visitor suddenly appeared before Markheim, "at times he thought he knew him, and at times he thought he bore a likeness to him".[1] The shadow (the mysterious visitor) can thus be perceived as another Markheim. It may seem absurd and illogical to split Markheim into two from the perspective of reality, but such absurdity is characteristic of a symbolic story: false illusions are mingled with reality. The conversation between the mysterious visitor and Markheim is actually a debate and conflict between the good and the evil in Markheim's innermost soul, which reflects the split nature of man: the duality of good and evil that both lurk inside people. Therefore, the shadow is actually the symbol of the good force in Markheim. That's why Markheim constantly felt the presence of moving shadows, as his conscience made him feel guilty of his own evil deeds. Through Stevenson's suspense stories like Markheim, Dr Jekyll and Mr. Hyde, it can be seen that Stevenson tends to be preoccupied with the nature of man and the nature of duality in man.[3]

Another object of great symbolic significance is the open door - the front door of the shop facing the street - which is mentioned quite a few times in this story. It is not until the end of the story that readers may realize it has implied meaning. After he killed the shop keeper, "at times, with a strong effort, he would glance at the open door which seemed to repel his eyes."'11] When reading this, readers may wonder: "Why does it take him such a strong effort to glance at the open door? Why does the open door repel his eyes?" The answer is not clear until readers read the words he said to the mysterious visitor who enticed him to further killing: "If I be condemned to evil acts, there is still one door of freedom open - I can cease from action." [1] Here it may be understood that the open door is the symbolic door of freedom, freedom from evil. That's why when Markheim committed the evil crime, the open door made him feel afraid of being found out and thus repelled his eyes. At the end of the story, the good in Markheim conquered the evil in him; he went through the open door and asked the maid who knocked at the door to call the police, instead of killing the maid to continue with the robbery in the shop. The theme of the story - the battle between the good and the evil - is 
thus further strengthened through the symbolic meaning of the open door: freedom from evil deeds.

Other objects in the background also have symbolic meaning in them, such as the hand glass and mirrors that reflect sins and the clocks that seem to be ticking away life. At the beginning of the story, Markheim entered the antique shop, intending to ransack the shop, but pretending to buy a Christmas present for his girlfriend. When the shop keeper showed him the hand glass as a choice, Markheim felt a shock and cried out: "I ask you for a Christmas present, and you give me this - this damned reminder of years, and sins and follies — this hand-conscience!"[1] His reaction at seeing the hand glass can reflect his inner heart: guilty of the sins that he is going to commit, afraid that the hand glass would mirror the evils in his mind. What the shop keeper perceived as a good gift for a lady - a hand glass that can reflect beauty - is what Markheim perceived as something to reflect sins. This reveals the symbolic meaning of the hand glass as a Christmas present. After he killed the shop keeper, the mirrors in the shop also made him aware of his sins. Similarly, the clocks that symbolize the elapse of time reminded him to hurry up with the robbery and thus created the psychological tension in him due to his worries about being found out. The use of these symbols is an effective way to manifest the theme: the struggle between good and evil, the conflict between virtues and sins.

\section{Symbolic Depiction of Sounds in the Background}

In this murder story, the writer also adopts auditory means to create the atmosphere of horror and the psychological tension in the murderer. Sounds, as opposed to silence, symbolize spiritual tumult instead of peace of mind. Silence of the shop was described quite a few times, in words like "the dumb chamber" and "the very silence of the place appeared a source of peril" [1] etc., but during "the interval of silence", Markheim kept hearing the ticking of the clocks, the beating of the rain, the creaking of the doors, the rushing of the cabs in the street, the gushing of the water in the pipes, the clink of the Bohemian goblets, the sound of a lad's running feet in the neighborhood and the sound of his own footsteps in the shop. All these sounds mingled together in his ears, and the "incessant echoing" of them in the empty house sounded all the more horrible, like the "echoes of pursuit" [1]. To describe sounds in a place of dead silence is really an effective way to create an atmosphere of horror. Sounds versus silence is actually a kind of symbolic contrast which is of great significance to strengthen the contrast between tumult and peace. After he committed the crime, "the sudden outbreak of so many tongues in that dumb chamber staggered him"[1]. Here the different sounds are compared to "outbreak of so many tongues", as if accusing him of his evil deeds. As his psychological tension increased, the ticking of the clock seemed so big as to sound like the beating of the clock, and he was so alarmed that he was tempted to stop the clock. With a guilty conscience, he was so startled by all the different sounds that he thought "how tranquilly he would possess his soul if he were deaf!"[1] Here it can be clearly understood that his soul was not at peace, instead it was filled with disturbance, while silence symbolizes tranquility and peace of mind. That's why at the end of the story, when he decided to cease from evil action and went toward the open door (which symbolizes door of freedom from evil), he looked back at the shop and felt "it was strangely quiet", and "he perceived a quiet haven for his bark"[1]. The quietness symbolizes that his heart retrieved peace, because he has purged his soul of evil, because the good force inside him has finally conquered the evil force.

As can be seen above, both the sounds in the background and the silence in the shop have symbolic meaning in them. The symbolic contrast between sounds and silence presents the conflict between evil and good. Similarly, the symbolic contrast between darkness and brightness (as described in the previous section in terms of candlelight and daylight) is also a way to reflect the combat between evil and good. Thus, the writer describes the background of the story as one with mingled shine and darkness, and with mingled sounds and silence, creating the atmosphere of horror to startle the murderer on the one hand and resorting to the use of symbolism to strengthen the theme on the other hand. Different from most story writers, Stevenson gives unusual prominence to the depiction of objects and sounds in the background, and successfully shows a significant relationship between the background and the theme. As the title of the story is Markheim - the name of the main character, one might take it for granted that the writer may put an emphasis on the depiction of the character, but actually the writer put the character in an symbolic background, through the careful description of which the psychological process of the character is reflected and the theme of the story is manifested. Namely, the writer describes the character through describing the background that all the time the character was in, showing the influence of the background on the character's psychological process, thus building up to the climax of the story and leading to the manifestation of the theme.

\section{Symbolic Meaning of the Time as an Integral Part of Background Setting}

As is stated above, in this story by Robert Stevenson, the background is depicted in a symbolic way in order to manifest the theme. Not only objects and sounds in the background are given symbolic meaning, even the choice of time for the story (as an integral part of the background setting) is given symbolic meaning as well. The writer made the murder story happen on a Christmas Day. There are three hundred and sixty-five days in a year, but why did the writer choose this particular day - Christmas - for a murder story? 
Actually there is a close relationship between the symbolic meaning of Christmas and the theme of this particular story (conflict between good and evil). Christmas is the day when Christ - the savior of the world - was born. In the Bible it says: "He (Christ) will save his people from their sins."[4] In this story, Markheim killed the shop keeper on a Christmas Day, which was clearly a sin. Then the good force and the evil force in him started to battle against each other, as he felt quite guilty at conscience. In the end, after the talk with the mysterious visitor, the good side of him conquered the evil side of him, and his soul was saved. All this happened on the day when Christ was born, born to save his people from their sins. That's why the theme of this story - good conquered evil - is best manifested by means of the choice of Christmas Day as the time for the murder to take place.

Since the time for the story was set on a Christmas Day, the background of the story was Christmas setting, which provided quite a special atmosphere for the surroundings in which the murder took place. Things concerning Christmas thus take on a symbolic meaning. Christmas present, Christmas hymn, voice of the parson are such examples. Christmas present is mentioned twice in this story: first, at the beginning of the story, when the shop keeper presented Markheim with a hand glass for him to buy as a Christmas gift for his girlfriend. And Markheim felt shocked at seeing it as he perceived it as something that could reflect the evil thoughts in his mind. It is symbolically significant that Markheim was presented such a Christmas present when he intended to commit evil doing. The second time Christmas gift is mentioned is at the end of the story, when Markheim had killed the shop keeper and the mysterious visitor appeared and offered him advice to complete his evil doing, saying: "I offer you the service for a Christmas gift."[1] However, after the talk with him about good and evil, Markheim refused his help and chose to cease from further evil action. Here it can be seen that actually the mysterious visitor used reverse psychology to push Markheim toward the choice of the good over the evil. The service that he offered to Markheim as a Christmas gift is actually not "help with evil doing" but "lesson for soul teaching", which made Markheim choose the opposite - the good. Markheim's soul was saved on the day that Christ was born, this is the most precious Christmas gift he has got. In this sense, the symbolic meaning of Christmas gift - teachings of the soul - helps to strengthen the theme of the story. The Christmas hymn that Markheim could hear from a nearby church and the voice of the parson that he could recall from his attendance to church in the past also have symbolic meaning. They symbolize peace, goodness and kindness, which were the typical atmosphere for Christmas, and served to christen Markheim's soul after he had committed the evil doing. Like the Christmas gift offered by the visitor, these are forces that drive him toward the good too. In a word, the choice of time for the story means more than it seems, and the symbolic meaning of it plays a great role in unveiling the theme: "hands of God reached forth against sin"[1], pulling
Markheim out of the evil and pushing him toward the good. It is shown by Stevenson how choice of time as an integral part of background setting can be made significant to revelation of the theme.

\section{Concluding Remarks}

To conclude, symbolism is the chief means used by Robert Stevenson when he wrote this story. His unusual emphasis on the symbolic depiction of the background greatly contributes to the theme of the story, while character and plot were made subordinate to the background. The background (surrounding/circumstance) has a great impact on the character in the story (or, generally, on all people), which can be either a positive influence or a negative one. In this story, Stock Exchange was mentioned twice, which symbolizes "the giant of circumstance"[1], dragging Markheim down to poverty and thus leading him to evil doing (robbery and murder). However, the Christmas atmosphere in the surroundings served as a positive force to Christen his soul and stop him from further evil action. The battle in his mind between good and evil goes on throughout the story until finally his soul was saved and transformation was achieved. The transformation has also borne symbolic significance to the theme of good over evil. As he turned to the good force, his mind eventually found its peace, no longer feeling those afflicting moments of psychological tension and living terror (caused by the objects and sounds in the background). His quarrel with his guilty conscience finally appeased as he made peace with God by ceasing from evil action. The symbolic contrast between previous psychological tension and eventual mental peace stands for the fact that good finally conquered evil. The symbolic contrast between brightness and darkness, and between sound and silence as described in previous sections also stand for the combat between good and evil. This story by Robert Stevenson is really a masterpiece to show the significance of a symbolic background, which both helps to create the atmosphere of horror for such a murder story and contributes to revelation of the murderer's psychology and manifestation of the theme. In conclusion, Markheim is a remarkable short story which shows how objects and sounds in the background can be endowed with symbolic meaning to reveal the theme of good conquering evil. In this sense, this story has not only literary techniques for contemporary writers to draw on, but also moral lessons for people under the "giant of circumstance" to learn from.

\section{REFERENCES}

[1] Stevenson,R.L.Markheim.1885. Available from http://www.doc88.com/p-108570440458.html

[2] Miller, R.K. The Transforming Drought: Jekyll and Hyde, 
Robert Louis Stevenson and the Alcohol Debate. Journal of Victorian Culture, 2008; 13(2):334-339.

[3] Stevenson, R.L. Markheim. Charleston: CreateSpace
Independent Publishing Platform;2013.

[4] Repschinki, B. "For He Will Save His People from Their Sins (Matthew 1:21): A Christology for Christian Jews. Catholic Biblical Quarterly, 2006; 68(2):248. 